\title{
Establishing prevalence in rare neuromuscular diseases
}

\section{A lesson from congenital myopathies} OPEN

Ahmed K. Bamaga, MD Conrad C. Weihl, MD, $\mathrm{PhD}$

Correspondence to Dr. Weihl: weihlc@wustl.edu

\section{Neurol Genet}

2017;3:e146; doi: 10.1212/ NXG.0000000000000146

\section{See article}

Congenital myopathies (CMs) are a heterogeneous group of early-onset muscle disorders with weakness, distinct histopathologic features, and normal to slightly elevated creatine kinase (CK). ${ }^{1}$ The age at onset and clinical severity can be variable, ranging from severely affected at birth to a milder later-onset disease. $^{2}$ Cardiac involvement has been reported. ${ }^{3,4}$ CMs are generally considered nonprogressive disorders. Three main categories are recognized within the classical CMs based on their typical histopathology: nemaline myopathy (NM), core myopathy, and centronuclear myopathy (CNM). Inheritance in CMs may be dominant, recessive, or X-linked. Greater than 25 unique genetic causes of CM have been identified and different types of mutations within the same gene (e.g., deletions, duplications, missense, nonsense, splice-site, and frameshift mutations) have been identified, as well as de novo dominant mutations. ${ }^{5}$

In this issue of Neurology ${ }^{\circledR}$ Genetics, Witting et al. ${ }^{6}$ report a comprehensive analysis of the prevalence, genotype, and phenotype of CM in patients 5 years and older in Denmark. The study was conducted at the Copenhagen neuromuscular center, Rigshospitalet, Denmark, in collaboration with the Danish National Rehabilitation Center for Neuromuscular Diseases. After identifying all registered Danish patients with a diagnosis of CM aged older than 5 years, comprehensive clinical, histopathologic, and genetic investigations were performed. This approach allowed for a unique prospective assessment of this patient group that has not been studied previously in CMs.

The study found that the prevalence of $\mathrm{CM}$ in Danish patients older than 5 years (age range 5-69 years with a mean of $\sim 28$ years) was 2:100,000; significantly lower than previous studies that estimated the prevalence at $\sim 4: 100,000 .^{7,8}$ This may be due to the exclusion of pediatric patients who have succumbed to their illness prior to age 5. This limitation, although acknowledged by the authors, underrepresents an entire group of early-onset CMs with high mortality in the first few years of life. This may also account for the lower prevalence of MTM1 mutations-carrying patients in this study. ${ }^{9,10}$

The prevalence did not include patients who phenotypically and pathologically fulfilled criteria for CM yet were found to have a genetic etiology considered not to be associated with CM. Whether this patient group was included in other studies is not entirely clear. However, 10 patients had mutations in DES, COLVI, COLXII, DOK7, and RAPSN. These patients are interesting because some had pathologic features of NM, core myopathy, and CNM. Notably, DES mutations were identified in one patient with NM and another with core myopathy. Whether these genes explain undiagnosed causes of $\mathrm{CM}$ in the global patient population remains to be determined. Notably, DES and genes associated with congenital myasthenic syndrome are not routinely included in CM gene panels. Therefore, neurologists should consider these etiologies in patients with CM and an unknown genetic cause.

A genetic etiology was reached in $56 \%$ of Danish $\mathrm{CM}$ patients. This is somewhat lower than in other similar studies in which a genetic cause was found in $67 \%-79 \%$ of patients. ${ }^{11,12}$ This may relate to the inclusion of patients without distinctive features on biopsy, but a phenotype consistent with CM. For example, in patients with histopathologic features consistent with NM, CNM, or core myopathy, a genetic diagnosis was identified in $83 \%$ of patients. By contrast, in patients with unspecific histopathologic features, the genetic diagnosis was achieved in only $21 \%$ of patients.

Another unique aspect of this study was the inclusion of patients with CM regardless of age. Indeed, the oldest patient was a 69-year-old woman with a DNM2 mutation. Although difficult to ascertain from the small cohort size, in general, older and younger patients with CM demonstrated a consistent phenotypic pattern of weakness depending on their gene mutation. Moreover, older patients with CM 
continued being active in their education or work life. This supports the prevailing theory that CM is a nonprogressive disorder.

Studies such as that performed by Witting et al., which define the prevalence and genetic heterogeneity of a defined patient population, are the next step in neuromuscular patient care. How the composition of Danish CM patients relates to other countries or even individual academic centers remains to be determined. Research initiatives focused on the identification of novel genetic etiologies are important, but reporting the genetic makeup of existing patient populations is absolutely essential, as we enter a new and exciting era of personalized neuromuscular therapeutics.

\section{STUDY FUNDING}

No targeted funding reported.

\section{DISCLOSURE}

Dr. Bamaga reports no disclosures. Dr. Weihl has served on scientific advisory board(s) for Novartis DSMB; has served on the editorial board of Neuromuscular Disorders; and has received research support from Ultragenyx Pharmaceuticals, NIH (AG031867; AG042095), Muscular Dystrophy Association, and Myositis Association. Go to Neurology.org/ng for full disclosure forms.

\section{REFERENCES}

1. Sewry CA, Wallgren-Pettersson C. Myopathology in congenital myopathies. Neuropathol Appl Neurobiol Epub 2016 Dec 15.

2. North KN, Wang CH, Clarke N, et al. Approach to the diagnosis of congenital myopathies. Neuromuscul Disord 2014;24:97-116.
3. Agrawal PB, Pierson CR, Joshi M, et al. SPEG interacts with myotubularin, and its deficiency causes centronuclear myopathy with dilated cardiomyopathy. Am J Hum Genet 2014;95:218-226.

4. Finsterer J, Stollberger C. Review of cardiac disease in nemaline myopathy. Pediatr Neurol 2015;53:473-477.

5. Nowak KJ, Ravenscroft G, Laing NG. Skeletal muscle alpha-actin diseases (actinopathies): pathology and mechanisms. Acta Neuropathol 2013;125:19-32.

6. Witting N, Werlauff U, Duno M, Vissing J. Phenotypes, genotypes, and prevalence of congenital myopathies older than 5 years in Denmark. Neurol Genet 2017;3:e140. doi: 10.1212/NXG.0000000000000140.

7. Amburgey K, McNamara N, Bennett LR, McCormick ME, Acsadi G, Dowling JJ. Prevalence of congenital myopathies in a representative pediatric United States population. Ann Neurol 2011;70:662-665.

8. Sveen ML, Schwartz M, Vissing J. High prevalence and phenotype-genotype correlations of limb girdle muscular dystrophy type 2I in Denmark. Ann Neurol 2006;59: 808-815.

9. Herman GE, Finegold M, de Gouyon B, Metzenberg A. Medical complications in long-term survivors with $\mathrm{X}$ linked myotubular myop. J Pediatr 1999;134:206-214.

10. Grogan PM, Tanner SM, Ørstavik KH, et al. Myopathy with skeletal asymmetry and hemidiaphragm elevation is caused by myotubularin mutations. Neurology 2005;64: 1638-1640.

11. Maggi L, Scoto M, Cirak S, et al. Congenital myopathiesclinical features and frequency of individual subtypes diagnosed over a 5-year period in the United Kingdom. Neuromuscul Disord 2013;23:195-205.

12. Colombo I, Scoto M, Manzur AY, et al. Congenital myopathies: natural history of a large pediatric cohort. Neurology 2015;84:28-35. 


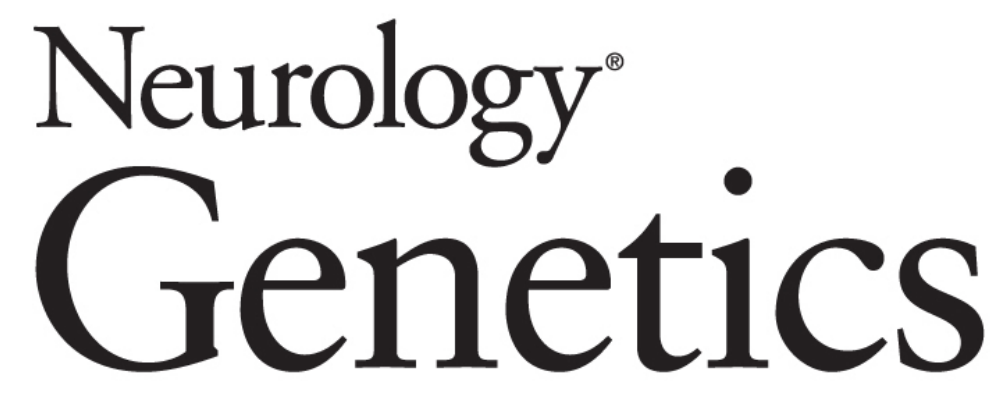

\section{Establishing prevalence in rare neuromuscular diseases: A lesson from congenital myopathies}

Ahmed K. Bamaga and Conrad C. Weihl

Neurol Genet 2017;3;

DOI 10.1212/NXG.0000000000000146

This information is current as of March 21, 2017

Updated Information \&

Services

References

Permissions \& Licensing

Reprints including high resolution figures, can be found at: http://ng.neurology.org/content/3/2/e146.full.html

This article cites 11 articles, 1 of which you can access for free at: http://ng.neurology.org/content/3/2/e146.full.html\#\#ref-list-1

Information about reproducing this article in parts (figures,tables) or in its entirety can be found online at:

http://ng.neurology.org/misc/about.xhtml\#permissions

Information about ordering reprints can be found online: http://ng.neurology.org/misc/addir.xhtml\#reprintsus

Neurol Genet is an official journal of the American Academy of Neurology. Published since April 2015, it is an open-access, online-only, continuous publication journal. Copyright Copyright $\odot 2017$ The Author(s). Published by Wolters Kluwer Health, Inc. on behalf of the American Academy of Neurology.. All rights reserved. Online ISSN: 2376-7839.

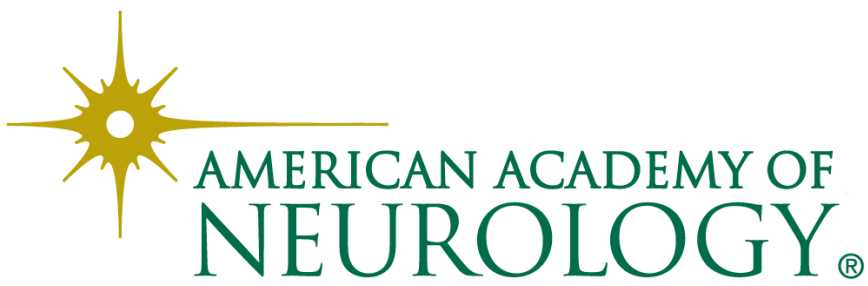

